9-9-2013

\title{
The Illustrated Guide to Criminal Law
}

Rebecca Mattson

Penn StateLaw, ram6023@psu.edu

Follow this and additional works at: http://elibrary.law.psu.edu/library_faculty

Part of the Legal Writing and Research Commons

\section{Recommended Citation}

Mattson, Rebecca, "The Illustrated Guide to Criminal Law" (2013). Law Library Faculty Works. 7.

http://elibrary.law.psu.edu/library_faculty/7

This Book Review is brought to you for free and open access by Penn State Law eLibrary. It has been accepted for inclusion in Law Library Faculty Works by an authorized administrator of Penn State Law eLibrary. For more information, please contact ram6023@psu.edu. 


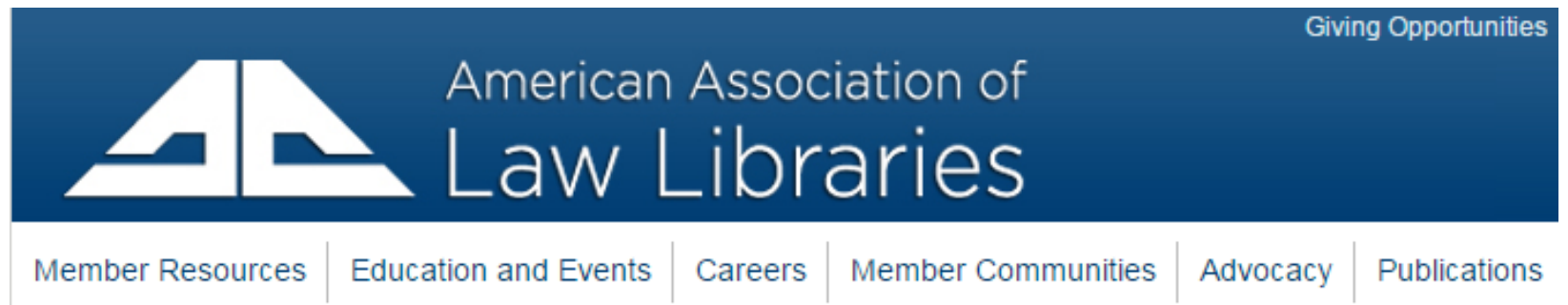

\section{Book Review - The Illustrated Guide to Criminal Law}

Home > Spectrum Blog > Book Review - The Illustrated Guide to Criminal Law

吕 四

Edit Post

BY: Rebecca Mattson | September 09,2013 at 11:22 AM TOPIC S: book reviews

The Illustrated Guide to Criminal Law, by Nathaniel Burney. Jones McClure Publishing; 2012, 260 pages. Paperback, $\$ 24.95$, ISBN 9781598391831.

Are you interested in criminal law? Are you taking criminal law? If yes, then The Illustrated Guide to Criminal Law is the book for you.

The author, Nathaniel Burney, is a defense attorney and former prosecutor. Burney first started this project in blog format as a way to debunk the myths surrounding criminal law ('ºu know, an undercover cop has to tell you if he's a cop. Otherwise, it's entrapment. NO.") The blog was well-received, and Burney turned his project into a full-length graphic novel.

The Illustrated Guide to Criminal Law is broken down into six sections: introduction on crime and punishment, the purposes of punishment, guilt, inchoate crimes, defenses, and concluding thoughts and examples. Burney uses plain language, wit, and illustrations to break down some of the more complicated pieces of criminal law. In addition to explaining terms and concepts, Burney creates fact patterns (similar to something one might find on a criminal law exam) to explain the interplay between each concept. Burney purposely avoids citing or discussing case law to make the book more accessible to the general reader.

This book is a must-have for law libraries as well as university libraries and public libraries. For law students, this book makes an excellent study aid, and for the general public, it is an easily read introduction to criminal law.

Rebecca Mattson is the Collection Development Librarian at the Cleveland-Marshall College of Law. 